\title{
Article \\ Advantage of Multiple Pods and Compound Leaf in Kabuli Chickpea under Heat Stress Conditions
}

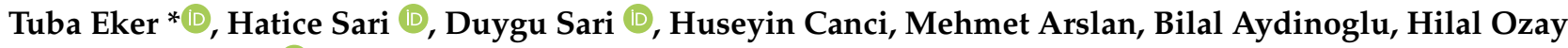 \\ and Cengiz Toker (1)
}

check for

updates

Citation: Eker, T.; Sari, H.; Sari, D.; Canci, H.; Arslan, M.; Aydinoglu, B.; Ozay, H.; Toker, C. Advantage of Multiple Pods and Compound Leaf in Kabuli Chickpea under Heat Stress Conditions. Agronomy 2022, 12, 557. https://doi.org/10.3390/ agronomy12030557

Academic Editors: Fernando Martinez-Moreno, Magdalena Ruiz, María B. Picó and María-José Díez

Received: 31 December 2021 Accepted: 18 February 2022 Published: 23 February 2022

Publisher's Note: MDPI stays neutral with regard to jurisdictional claims in published maps and institutional affiliations.

Copyright: (c) 2022 by the authors. Licensee MDPI, Basel, Switzerland. This article is an open access article distributed under the terms and conditions of the Creative Commons Attribution (CC BY) license (https:// creativecommons.org/licenses/by/ $4.0 /)$.
Department of Field Crops, Faculty of Agriculture, Akdeniz University, Antalya 07070, Turkey; haticesari@akdeniz.edu.tr (H.S.); duygusari@akdeniz.edu.tr (D.S.); huseyincanci@akdeniz.edu.tr (H.C.); mehmetarslan@akdeniz.edu.tr (M.A.); aydinoglu@akdeniz.edu.tr (B.A.); hilalfarsak@gmail.com (H.O.); toker@akdeniz.edu.tr (C.T.)

* Correspondence: ekertuba07@gmail.com; Tel.: +90-242-310-24-21

Abstract: Heat-related traits in chickpea (Cicer arietinum L.) play a crucial role in reducing the harmful effect of heat stress, as the increase in heat stress is predicted to occur in the coming years due to global warming as a result of climate change. The advantage of multiple pods per peduncle and compound (imparipinnate) leaf traits in kabuli chickpea has not been properly revealed under heat stress conditions. We, therefore, want (i) to provide insight into the advantage of multiple pods and compound leaf traits over single pod per node and simple (unifoliolate) leaf traits, and (ii) to determine the highest direct and indirect effects of agro-morphological traits on seed yield in chickpeas under rainfed conditions with prevailing heat stress. With a delayed sowing time, the plants were subjected to heat stress of more than $43^{\circ} \mathrm{C}$ in flowering and pod setting stages under field conditions. According to the number of pods per node and leaf shape, plants were evaluated for yield and yield components, and were divided into six groups, namely (i) single-pod and compound leaf, (ii) single-pod and simple leaf, (iii) double-pods and compound leaf, (iv) double-pods and simple leaf, (v) multi-pods and compound leaf, and (vi) multi-pods and simple leaf. Plants with multi-pods and compound leaf traits had the highest seed yield, followed by plants with double-pods and compound leaf, while plants with single-pod and simple leaf had the lowest yield. The number of seeds and pods per plant, 100-seed weight, and leaf shape were the highest determinants of seed yield under heat stress conditions. It was concluded that multi-pods per peduncle and compound leaf traits had an obviously incontrovertible advantage in kabuli chickpeas under heat stress conditions. The plant shapes that nature has evolved for millions of years, which are mostly found in wild plants, have been proven by the current study to have a better fitness ability than plants shaped by human hands.

Keywords: Cicer arietinum; heat stress; multi-pods; double-pods; compound leaf

\section{Introduction}

Cultivated chickpea (Cicer arietinum L.) is divided into two different varietal groups, namely "desi" and "kabuli", and "desi" chickpeas are portrayed with small seeds, different seeds in colors including brown, black, and green, with pinkish-purple flowers and pigmented plants, while "kabuli" chickpeas have large seeds, are cream in color, with white flowers and non-pigmented plants [1]. Both chickpeas are predominantly grown in arid and semi-arid areas of the world under rainfed conditions [2,3]. As they are dependent on these growing conditions, the majority of the crop is exposed to continuous limiting soil moisture and high temperature during flowering and pod setting stages, despite the fact that the crop is adapted to temperate regions as an important cool season food legume [3,4]. According to the Food and Agriculture Organization Statistical Database (FAOSTAT) in 2020, the cultivation area and production quantity of chickpeas in the world have been reported to be 14.8 million ha and 15.1 million $t$, respectively. The average seed yield of 
chickpeas is reported to be as low as $1016 \mathrm{~kg}$ per ha [5], despite the fact that the seed yield potential of chickpeas is on par with the other food legumes [6]. The main reason for the low seed yield of chickpeas is based on the adverse effect of a/biotic stresses, because chickpeas are grown in marginal areas without using input or with minimum input under rainfed conditions, although they are endowed with some agro-morphological and physiological characteristics that make it possible to settle them into marginal areas where there are prevailing a/biotic stresses [6,7].

The optimum temperatures for chickpeas range from 18 to $29^{\circ} \mathrm{C}$ for growth and development [1], despite the fact that most of the cultivated areas of chickpeas have suffered from excessive temperatures that accelerated drought $[2,8,9]$. Temperatures above $32{ }^{\circ} \mathrm{C}$ in the daytime are detrimental, resulting in lower pod sets and seed yields in chickpeas [7]. The predicted changes in temperature in the world are expected to be in the range of $2-3{ }^{\circ} \mathrm{C}$ in the near future $[10,11]$. Due to heat stress, yield losses in chickpeas have been reported to range from 10 to $78 \%$ of the potential yield for every increase of one degree in temperature $[12,13]$. Under these circumstances, heat stress caused by heatwaves and extreme temperatures occurring during the period from the end of spring to summer has a dramatic impact on the productivity of cultivated chickpeas. However, in a number of research carried out on heat tolerance in cultivated chickpeas [8,13-17] and its wild relatives [18], resistance sources for heat tolerance have been found to be insufficient. Heat tolerance in recombinant inbred lines generated from intraspecific crosses in chickpeas has been studied [17].

The relationship between some morpho-physiological traits of chickpeas and drought stress accompanying high temperature stress has been studied [8,13,19-22]. One of the most striking morphological traits of chickpeas is undoubtedly their leaf shape. Three different leaf shapes in cultivated chickpeas, namely compound or fern-like (imparipinnate), simple (unifoliolate), and multipinnate (bipinnate) leaves [23,24], have been reported, and the inheritance of the traits was studied [25-27], and it was concluded that these traits were not affected by the environment due to their qualitative nature. Like wild Cicer species $[1,28]$, the compound leaf shape is common in most cultivated chickpeas commercially grown in the world. Cultivars with simple leaf shapes have been improved by Muehlbauer et al. [29,30], for resistance to ascochyta blight caused by Ascochyta rabiei (Pass.) Labr. Despite advantages of multipinnate leaf shape in cultivated chickpeas, such as resistance to leafminer (Liriomyza cicerina Rond.) and reducing water loss by transpiration [31-33], they have not been taken into account much in chickpea production. Under heat stress conditions, the effect of leaf shape on yield in cultivated "kabuli" chickpeas deserves attention, as no information is available on this issue.

Another important trait of chickpeas is the number of flowers or pods per peduncle (node or axil), and most cultivated chickpea cultivars usually carry a single flower, and a single flower forms a single pod per peduncle $[23,24]$. On the other hand, some cultivated chickpeas form double flowers and double pods (see details in Kivrak et al. [34]) as wild chickpeas $[1,28]$. Double-podded chickpeas, reported in cultivated chickpeas, provide more seed yields in favorable conditions [34-36] and yield stability [37,38]. However, the seed yield of multi-podded chickpeas has not been compared with double-podded chickpeas nor single-podded chickpeas under heat stress conditions. Insight into heat-related architectural shapes in chickpeas plays a crucial role in reducing the detrimental effect of heat stress, as an increase in heat stress is forecasted in the near future due to global warming. The current study is therefore aimed at: (i) gaining insight into the advantages of multiple pods and compound leaf traits over single pod per node and simple (unifoliolate) leaf traits, and (ii) finding out the highest direct and indirect effects of agro-morphological traits on seed yield in "kabuli" chickpeas under rainfed conditions with prevailing heat stress. 


\section{Materials and Methods}

\subsection{Plants}

Plants from $\mathrm{F}_{3}$ and $\mathrm{F}_{4}$ populations were advanced from intraspecific crosses between PI 631078 simple-leafed (unifoliolate) and single-podded [39], and PI 632396 compoundleafed (imparipinnate) and double-podded [40]. According to the mentioned intraspecific crosses, six different architectural groups have been recognized [34,41], namely (i) singlepod and compound leaf, (ii) single-pod and simple leaf, (iii) double-pods and compound leaf, (iv) double-pods and simple leaf, (v) multi-pods and compound leaf, and (vi) multipods and simple leaf. Detailed information about parents and checks, including ILC 3279, ILC 1929, ICC 12004, ILC 482, and ILC 72, is provided in Table 1. Figure 1 shows leaf shape and number of flowers per peduncle in cultivated "kabuli" chickpeas.

Table 1. Agro-morphological traits and reaction to ascochyta blight of checks and parents.

\begin{tabular}{cccccc}
\hline $\begin{array}{c}\text { Parents and } \\
\text { Checks }\end{array}$ & Kabuli/Desi & Flower Color & $\begin{array}{c}\text { Pods per } \\
\text { Peduncle }\end{array}$ & Leaf Shape & 100-Seed Weight (g) \\
\hline $\begin{array}{c}\text { PI 631078 } \\
\text { (Sierra) }\end{array}$ & Kabuli & White & 1 & Simple & Resistant \\
\hline $\begin{array}{c}\text { PI 632396 } \\
\text { (CA 2969) }\end{array}$ & Kabuli & White & 2 & Compound & 28.9 \\
\hline ILC 72 & Kabuli & White & 1 & Compound & 23.2 \\
\hline ILC 482 & Kabuli & White & 1 & Compound & 23.5 \\
\hline ILC 1929 & Kabuli & White & 1 & Compound & 25.5 \\
\hline ILC 3279 & Kabuli & White & 1 & Compound & 24.3 \\
\hline ICC 12004 & Desi & Purple & 1 & Compound & 9.1 \\
\hline
\end{tabular}
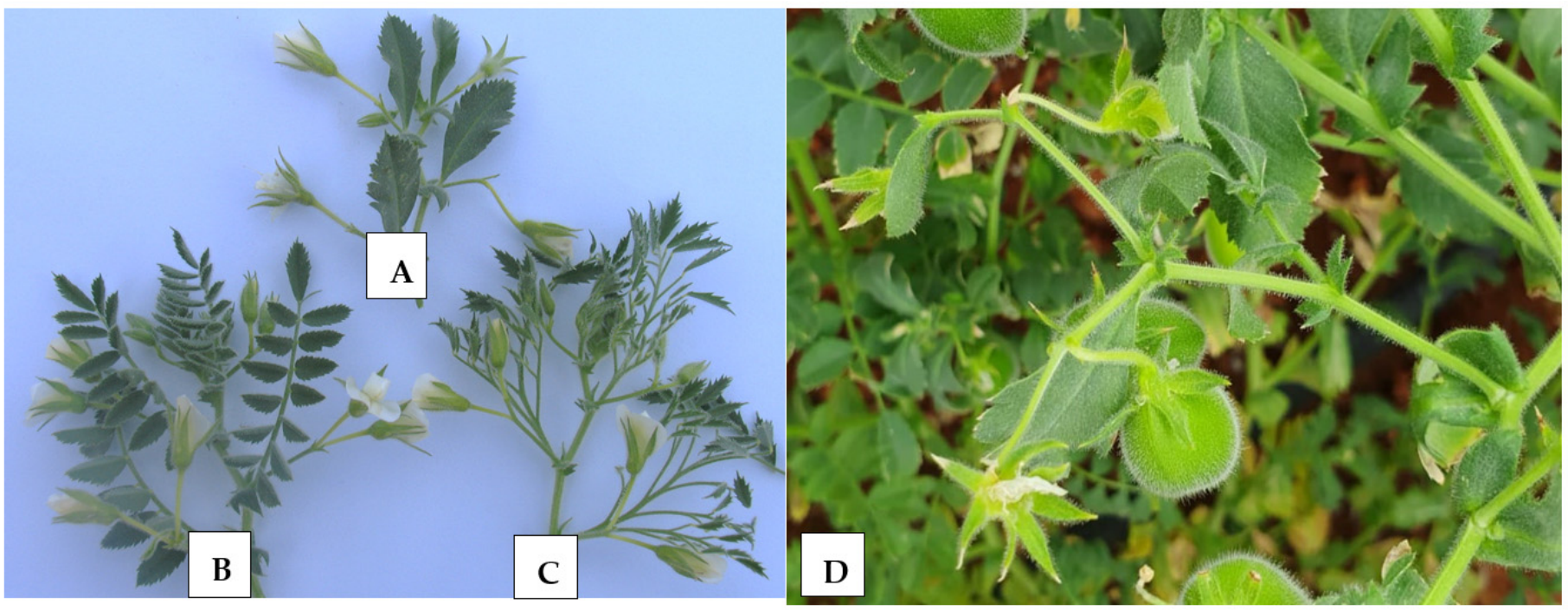

Figure 1. Leaf types and number of flowers per peduncle in cultivated chickpeas. (A) Simple-leafed and single-podded (Sierra), (B) compound-leafed and double-podded (CA 2969), (C) multipinnateleafed and double-podded (Mutant), and (D) simple-leafed and multi-podded.

\subsection{Sowing and Growing Procedures}

Seeds of chickpeas were sown on 4 April 2019 and 4 March 2020 at the campus of Akdeniz University, Antalya, Turkey $\left(30^{\circ} 38^{\prime} \mathrm{E}, 36^{\circ} 53^{\prime} \mathrm{N}, 51 \mathrm{~m}\right.$ above sea level), for two years. Late sowings were preferred to coincide with heat stress and the flowering time of the chickpeas. Plants including parents and checks were grown in rows of $2 \mathrm{~m}$ in length. Inter row spacing of $50 \mathrm{~cm}$ and intra row spacing of $10 \mathrm{~cm}$ were adopted. In $\mathrm{F}_{3}$ and $\mathrm{F}_{4}$, 1214 and 485 plants were grown, respectively, and each plant was harvested as a single 
plant. PI 631078 and PI 632396 were used as parents and the earlier mentioned checks were replicated four times. Plants were irrigated using a drip irrigation system with a drip lateral line, which had emitters with $2 \mathrm{~L}$ per hour and $20 \mathrm{~cm}$ emitter spacing to each plant row, and they were well-watered at three-day intervals as the plants were only subjected to heat stress. During seedling and before the flowering stages, the weeds were pull out by hand. Fertilization was not applied as fertilization was not used in spring-sown crops due to a negative effect.

\subsection{Phenological Traits}

Phenology plays a critical role in resistance to drought and heat stresses [6,42,43], and two important phenological traits, namely days to first flowering (FF) and days to $50 \%$ flowering (DF), were recorded as the number of days from germination to first flowering and $50 \%$ flowering, respectively.

To assess the temperature intensity, the averages of the maximum temperatures $\left({ }^{\circ} \mathrm{C}\right)$ from germination to flowering $\left(T_{\max } \mathrm{F}\right)$ and from flowering to harvest $\left(T_{\max \mathrm{FH}}\right)$ were calculated for each chickpea. Similarly, cumulative growing degree-days (GDD) for each chickpea were calculated from germination to flowering and from flowering to harvest, and were denoted as $\mathrm{GDD}_{\mathrm{F}}$ and $\mathrm{GDD}_{\mathrm{FH}}$, respectively. The following formula was used to calculate the GDD values [44]:

$$
\mathrm{GDD}=\sum\left(\frac{T_{\max }+T_{\min }}{2}-T_{b}\right)
$$

where $T_{\max }, T_{\min }$, and $T_{b}$ are the maximum, minimum, and base temperatures, respectively. The base temperature is the minimum threshold temperature below which plant development stops. The base temperature in chickpeas is considered $0{ }^{\circ} \mathrm{C}$ [45].

\subsection{Agro-Morphological Traits}

For agro-morphological traits, plant height $(\mathrm{PH})$ was recorded as $\mathrm{cm}$ from the ground to top of the plant, while the number of pods (PP) and seeds (SP) were counted as the total number of pods and seeds per plant, respectively. Seed yield (SY) was weighted as the total weight of a single plant after harvest, whereas seed size (SW) was determined using the following formula $[34,41]$ :

$$
100-\text { seed weight }(\mathrm{g})=\frac{\text { Total seed weight per plant }(\mathrm{g})}{\text { Total number of seeds per plant }} \times 100
$$

\subsection{Qualitative Traits}

The number of pods per peduncle (node or axil) as single, double, and multiple pods and leaf shape as compound-leafed or fern-like and simple-leafed or unifoliolate leaves were evaluated for each plant.

\subsection{Climatic Data}

Climatic data for the growing seasons were provided by the fourth Regional Directorate of Meteorology of the Turkish State Meteorological Service (TSMS) at the campus of Akdeniz University. Cumulative degree-days for optimum growth (DDO) were calculated using the formula below and the optimum temperature was considered to be up to $29^{\circ} \mathrm{C}$, while the cumulative degree-days for heat stress $(\mathrm{DDH})$ were calculated following the formula considering for the heat threshold as $29{ }^{\circ} \mathrm{C}$ in chickpeas. Formulas were modified from the equation of Krese et al. [46]:

$$
\begin{aligned}
& \text { For } T_{\text {max }}<T_{b}, \mathrm{DDO}=\sum_{i=1}^{n}\left(T_{b}-T_{\text {max }}\right) \\
& \text { For } T_{\text {max }}>T_{b}, \mathrm{DDH}=\sum_{i=1}^{n}\left(T_{\max }-T_{b}\right)
\end{aligned}
$$


where DDO and DDH are the cumulative sums of optimum growth degree-days and heat stressed degree-days for $\mathrm{n}$ days, and $\mathrm{n}$ is the total days in the period. $T_{b}$ is the base temperature for heat stress in chickpeas, and $T_{\max }$ is the maximum temperature. The base temperature is considered to be $29^{\circ} \mathrm{C}$.

\subsection{Statistical Analyses}

All agro-morphological data were analyzed for descriptive statistics using IBM SPSS statistics (2014). Moreover, plants were divided into six classes to compare (i) single-pod and compound leaf, (ii) single-pod and simple leaf, (iii) double-pods and compound leaf, (iv) double-pods and simple leaf, (v) multi-pods and compound leaf, and (vi) multipods and simple leaf. Data on phenological and agro-morphological traits of parents and checks were statistically analyzed through analysis of variance (ANOVA) using SPSS 22.0. The comparison of the averages of the analyzed agro-morphological traits was performed using Tukey's Multiple Comparison Test at $p \leq 0.05$. Furthermore, direct and indirect relationships of agro-morphological traits on seed yield of the single-podded plants, double-podded plants, and multi-podded plants in $\mathrm{F}_{4}$ were studied via path coefficients according to Dewey and Lu [47] using SPSS 22.0. Path coefficients are used by breeders/researchers for determining the direct contribution of agro-morphological traits and the indirect contribution over other traits on seed yield [48]. Principal component analysis (PCA) was carried out using JMP Pro 16.0.0 (SAS Institute Inc., Cary, NC, USA). A hierarchical cluster analysis (HCA) was performed on seed yield values using JMP Pro 16.0.0 according to Ward's method to analyze the studied chickpeas, parents, and checks under heat stress conditions.

\section{Results}

\subsection{Heat Stress}

Chickpeas were exposed to significant heat stress, especially during flowering and pod setting periods, for both years (Figure 2 and Figure S1). During the flowering and pod setting periods, the average maximum temperature was recorded to be $30.8 \pm 0.56{ }^{\circ} \mathrm{C}$ and $29.2 \pm 0.74{ }^{\circ} \mathrm{C}$ in 2019 and 2020, respectively. During the same periods, high temperatures above $29^{\circ} \mathrm{C}$ were observed for 27 days and the highest temperature during this period was recorded as $40{ }^{\circ} \mathrm{C}$ in 2019. In May and June 2020, high temperatures above $29^{\circ} \mathrm{C}$ were recorded for 21 days and there was a period of consecutive extreme temperatures between May 15 and May 20, while the highest temperature was recorded as $43.1^{\circ} \mathrm{C}$ in flowering (Figure S1). Cumulative degree-days for heat stress (DDH) and optimum growth (DDO) were 106.4 and $27.4{ }^{\circ} \mathrm{C}$ days in 2019 , while they were 127.8 and $118.6{ }^{\circ} \mathrm{C}$ days in 2020, respectively (Figure 2).

Values for growing degree-days from germination to flowering $\left(\mathrm{GDD}_{\mathrm{F}}\right)$ were higher in compound-leafed chickpeas than that of simple-leafed chickpeas in both years (Table S1). In contrast, growing degree-days from flowering to harvest $\left(\mathrm{GDD}_{\mathrm{FH}}\right)$ had higher values in simple-leafed chickpeas than that of compound-leafed chickpeas in both years (Table S1).

As seen in Table 2, seed yield in general was significantly correlated with $T_{\max } \mathrm{FH}$, $\mathrm{GDD}_{\mathrm{F}}$, and $\mathrm{GDD}_{\mathrm{FH}}$. The closest relationships between seed yield and $T_{\max \mathrm{FH}}, \mathrm{GDD}_{\mathrm{F}}$, and $\mathrm{GDD}_{\mathrm{FH}}$ are given in Table 2. A significant negative correlation between seed yield and $T_{\max } \mathrm{F}\left(\mathrm{r}=-0.406^{*}\right)$ was observed in simple-leafed and multi-podded chickpeas. Similarly, a significant negative correlation between seed yield and $T_{\max \mathrm{FH}}(\mathrm{r}=-0.524 * *)$ was found in simple-leafed and multi-podded chickpeas. There was a significant negative relationship between seed yield and $\mathrm{GDD}_{\mathrm{F}}$. On the other hand, the closest association between seed yield and $\mathrm{GDD}_{\mathrm{FH}}\left(\mathrm{r}=0.436^{* *}\right)$ was detected in simple-leafed and single podded chickpeas. 

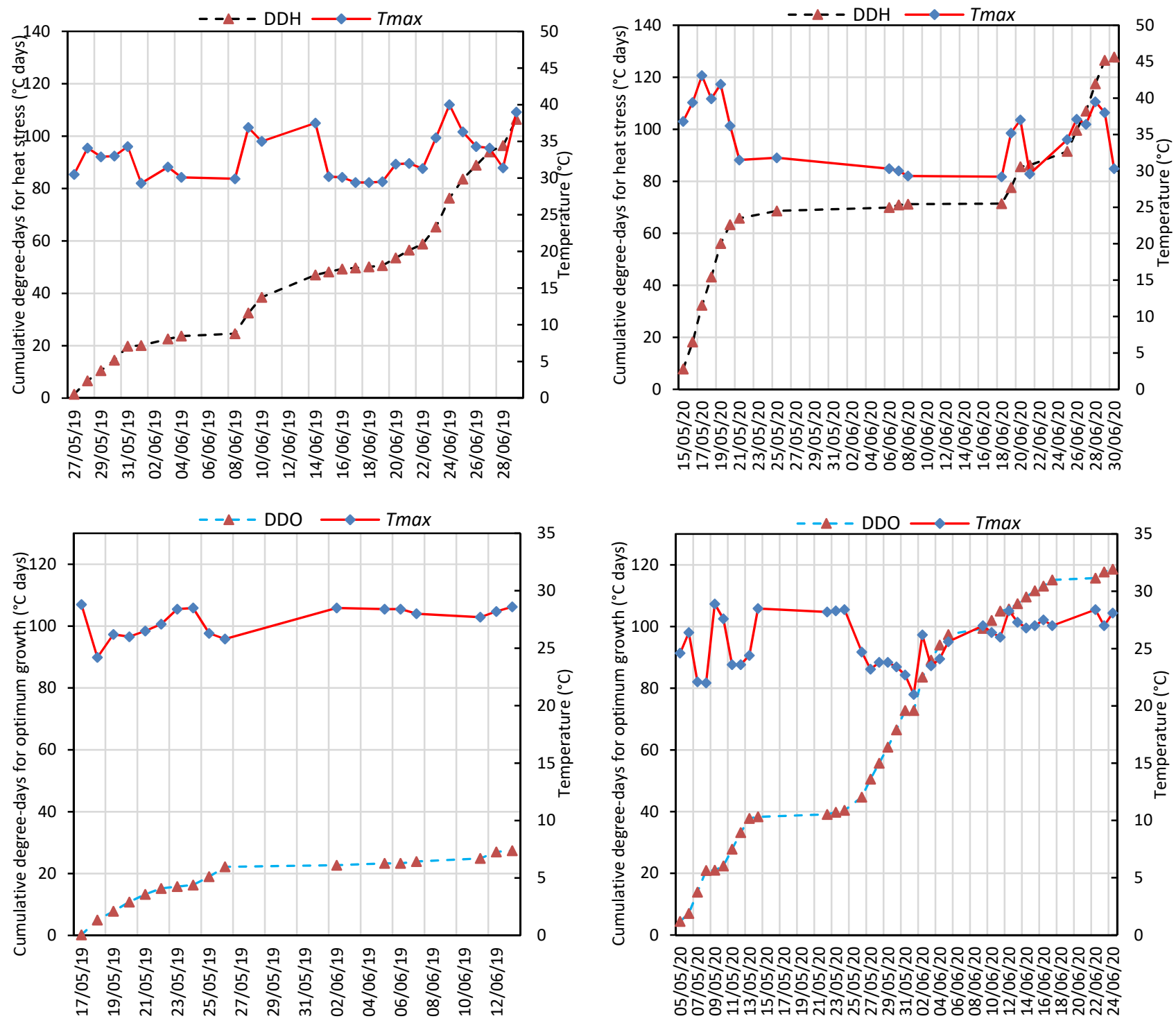

Figure 2. Cumulative degree-days for heat stress (DDH) and optimum growth (DDO) according to heat threshold temperature $\left(29^{\circ} \mathrm{C}\right)$ and daily maximum temperatures $\left(T_{\max }\right)$ during flowering and pod setting stages in the 2019 and 2020 growing seasons.

\subsection{Nutrient Elements and Soil Properties}

Phosphorus (with $9.4 \mathrm{ppm}$ ), potassium (with 0.6 meq per $100 \mathrm{~g}$ ), calcium (with 37.7 meq per $100 \mathrm{~g}$ ), magnesium (with 7.1 meq per $100 \mathrm{~g}$ ), mangan (with $2.3 \mathrm{ppm}$ ), and copper (with $1.4 \mathrm{ppm}$ ) were found to be at a sufficient level, while organic matter (with $1.9 \mathrm{ppm}$ ) and total nitrogen (with $0.1 \%$ ), iron (with $3.6 \mathrm{ppm}$ ), and zinc (with $0.8 \mathrm{ppm}$ ) were determined to be at a low level owing to high $\mathrm{pH}(8.0)$. Soil texture was loam with $\mathrm{CaCO}_{3}$ of $26.5 \%$, while electrical conductivity was $0.9 \mathrm{mS}$ per $\mathrm{cm}$.

\subsection{Phenological Traits}

According to the ANOVA results, the effect of chickpeas was found to be significant, while the $\mathrm{G}$ by $\mathrm{Y}$ interaction was significant for days to first flowering, days to $50 \%$ flowering, plant height, seed yield, and 100-seed weight, while it was not significant for pods and seeds per plant $(p \leq 0.05)$ (data not shown). 
Table 2. Correlation coefficients ( $\mathrm{r}$ ) between seed yield and maximum temperatures from germination to flowering $\left(T_{\max }\right)$ and from flowering to harvest $\left(T_{\max \mathrm{FH}}\right)$, and growing degree-days from germination to flowering $\left(\mathrm{GDD}_{\mathrm{F}}\right)$ and from flowering to harvest $\left(\mathrm{GDD}_{\mathrm{FH}}\right)$.

\begin{tabular}{|c|c|c|c|c|c|c|}
\hline \multirow{2}{*}{ Year } & \multirow{2}{*}{ Leaf Shape } & \multirow{2}{*}{ Pods per Axil } & $T_{\max \mathrm{F}}$ & $T_{\max \mathrm{FH}}$ & GDD $_{F}$ & $\mathrm{GDD}_{\mathrm{FH}}$ \\
\hline & & & SY & SY & SY & SY \\
\hline \multirow{8}{*}{2019} & \multirow{4}{*}{ Compound } & Single & -0.012 & $-0.197^{* *}$ & $-0.294^{* *}$ & $0.294^{* *}$ \\
\hline & & Double & 0.020 & $-0.192 * *$ & $-0.328^{* *}$ & 0.328 ** \\
\hline & & Multi & 0.109 & -0.134 & $-0.311 *$ & 0.325 * \\
\hline & & All & 0.018 & $-0.184^{* *}$ & $-0.308^{* *}$ & $0.307^{* *}$ \\
\hline & \multirow{4}{*}{ Simple } & Single & -0.086 & $-0.259 * *$ & $-0.308^{* *}$ & $0.310^{* *}$ \\
\hline & & Double & -0.080 & $-0.284^{* *}$ & $-0.379 * *$ & $0.379 * *$ \\
\hline & & Multi & 0.088 & -0.120 & -0.200 & 0.200 \\
\hline & & All & -0.067 & $-0.255^{* *}$ & $-0.328^{* *}$ & $0.328^{* *}$ \\
\hline \multirow{8}{*}{2020} & \multirow{4}{*}{ Compound } & Single & 0.068 & 0.248 * & $-0.421^{* *}$ & $0.408^{* *}$ \\
\hline & & Double & $0.209 * *$ & 0.174 * & $-0.213^{* *}$ & $0.206^{* *}$ \\
\hline & & Multi & 0.142 & 0.261 & 0.185 & -0.173 \\
\hline & & All & $0.158^{* *}$ & $0.199^{* *}$ & $-0.272 * *$ & $0.264^{* *}$ \\
\hline & \multirow{4}{*}{ Simple } & Single & 0.003 & 0.071 & $-0.432^{* *}$ & $0.436^{* *}$ \\
\hline & & Double & 0.128 & -0.018 & $-0.249 *$ & 0.243 * \\
\hline & & Multi & $-0.406^{*}$ & $-0.524^{* *}$ & $-0.440 * *$ & $0.408^{* *}$ \\
\hline & & All & -0.011 & -0.067 & $-0.354^{* *}$ & $0.347^{* *}$ \\
\hline
\end{tabular}

Phenological traits such as days to first flowering and days to 50\% flowering in 2019 were found earlier than that of 2020. ICC 12004 had the earliest days to first flowering and days to $50 \%$ flowering. According to leaf shape and pods per axil, there was no difference for phenological traits (Figure 3).

\subsection{Plant Height}

In 2019, plant height was 44.8 for compound-leafed chickpeas, whereas it was $50.6 \mathrm{~cm}$ for simple-leafed chickpeas. In 2020, plant height was $52.1 \mathrm{~cm}$ for compound-leafed chickpeas, while it was $55.4 \mathrm{~cm}$ for simple-leafed chickpeas (Figure 4). Multi-podded chickpeas had a higher plant height than that of single- $(6.5 \%)$ and double-podded $(2.2 \%)$ chickpeas based on both years (Figure 4).

\subsection{Pods per Plant}

The number of pods per plant was found to be 68.9 for compound-leafed chickpeas, while it was 49.5 for simple-leafed chickpeas in 2019. The number of pods per plant was 44.4 for compound-leafed chickpeas, whereas it was 32.2 for simple-leafed chickpeas in 2020 (Figure 4). For number of pods per plant, a significant difference between compoundand simple-leafed chickpeas was detected. Compound-leafed chickpeas had more pods per plant $(57.7 \%)$ compared to simple-leafed chickpeas. In both compound- and simpleleafed chickpeas, multi-podded chickpeas had the highest pods per plant for both years (Figure 1D), while compound-leafed and multi-podded chickpeas had the highest pods per plant (Figure 4).

\subsection{Seeds per Plant}

The number of seeds per plant was determined as 79 for compound-leafed chickpeas, whereas it was 52.3 for simple-leafed chickpeas in 2019. The number of seeds per plant was found to be 48.8 for compound-leafed chickpeas, while it was 33.7 for simple-leafed chickpeas in 2020 (Figure 4). Compound-leafed chickpeas had $48.6 \%$ more seeds than simple-leafed chickpeas for both years. Multi-podded chickpeas had $13.8 \%$ and $21 \%$ more seeds per plant than that of double-podded and single-podded chickpeas, respectively. Multi-podded chickpeas had the highest seeds per plant in both compounds- and simple- 
leafed chickpeas for both years, whereas compound-leafed and multi-podded chickpeas had the highest seeds per plant (Figure 4).

\subsection{Seed Yield}

In 2019, compound-leafed chickpeas had a seed yield of $26.8 \mathrm{~g}$, whereas simple-leafed chickpeas had a seed yield of $16.1 \mathrm{~g}$. In 2020, seed yield for compound-leafed chickpeas was $18.2 \mathrm{~g}$, while seed yield for simple-leafed chickpeas was $11.8 \mathrm{~g}$ (Figure 5). Seed yield had a significant difference between compound-leafed chickpeas and simple-leafed chickpeas. Compound-leafed chickpeas had a higher seed yield (60.7\%) than simple-leafed chickpeas in both years. Multi-podded chickpeas had 7.8\% and 20.5\% more seed yield than that of double-podded and single-podded chickpeas in both years, respectively. Multi-podded and compound-leafed chickpeas had the highest seed yield (Figure 5).
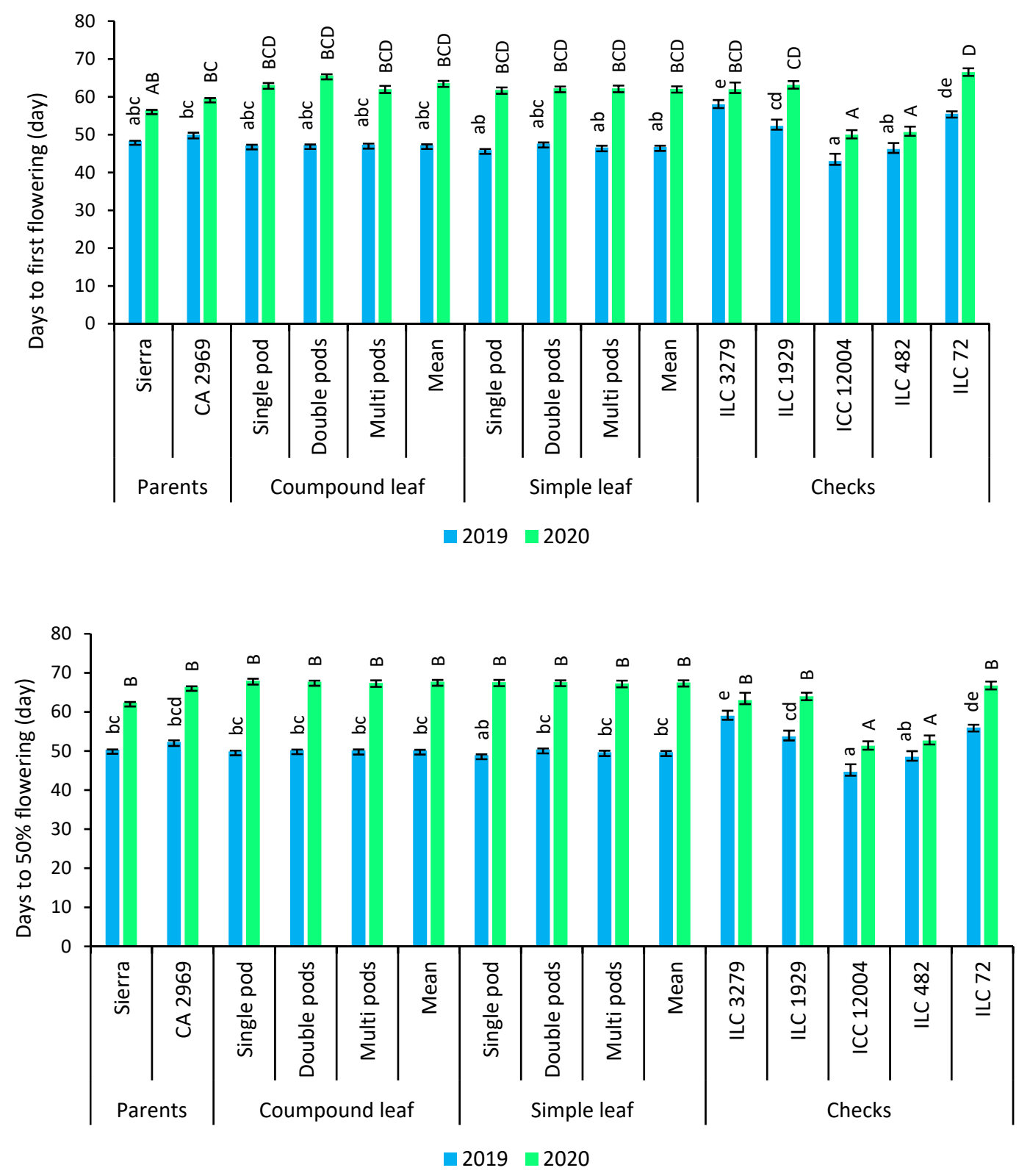

Figure 3. Comparison of compound-leafed versus simple-leafed and multi-podded versus doublepodded and single-podded chickpeas with parents and checks for phenological traits. Different lowercase letters and uppercase letters represent the significant difference $(p \leq 0.05)$ between the means for 2019 and 2020, respectively. 

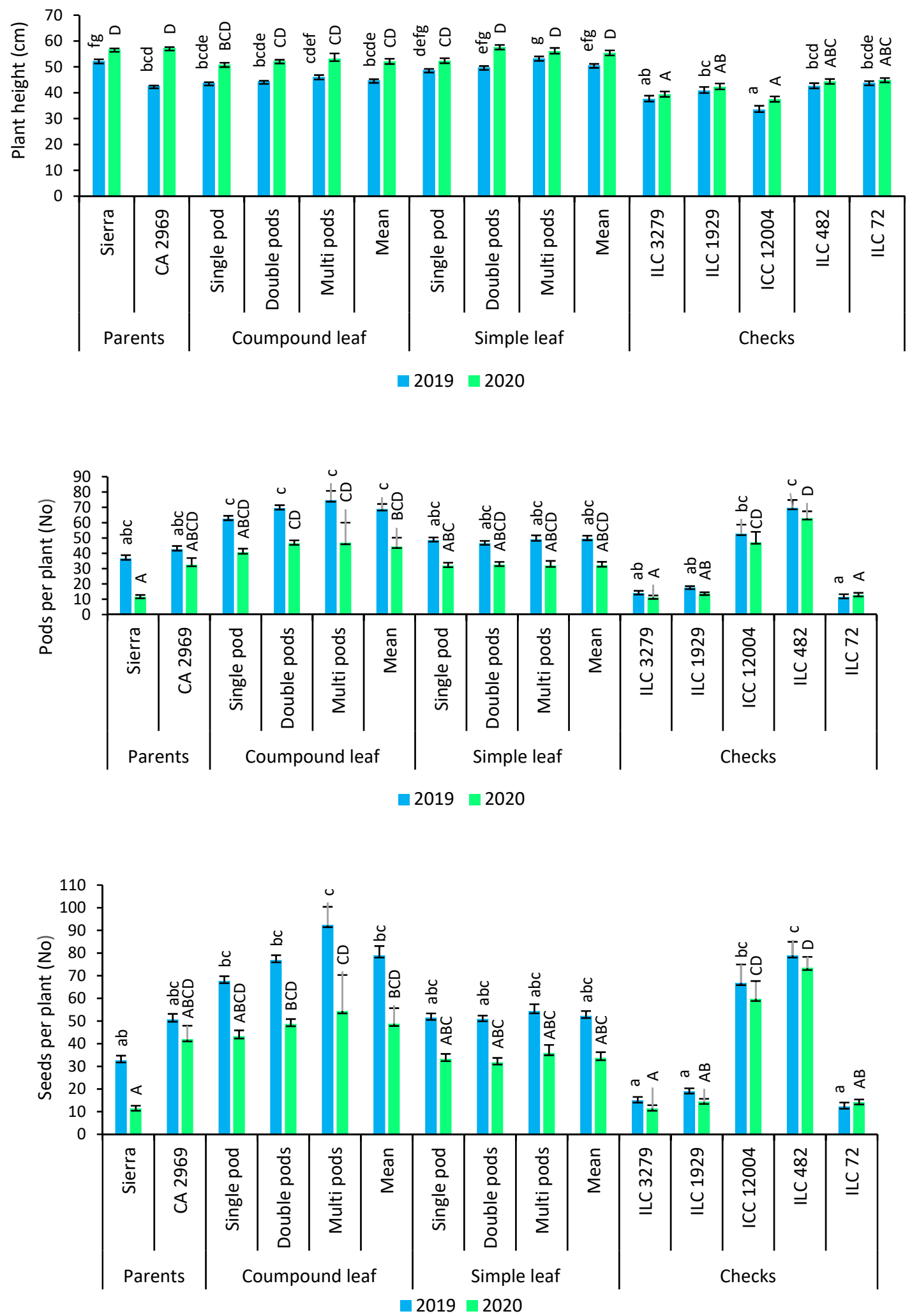

Figure 4. Comparison of compound-leafed versus simple-leafed and multi-podded versus doublepodded and single-podded chickpeas with parents and checks for plant height, pods and seeds per plant. Different lowercase letters and uppercase letters represent the significant difference $(p \leq 0.05)$ between the means for 2019 and 2020, respectively. 

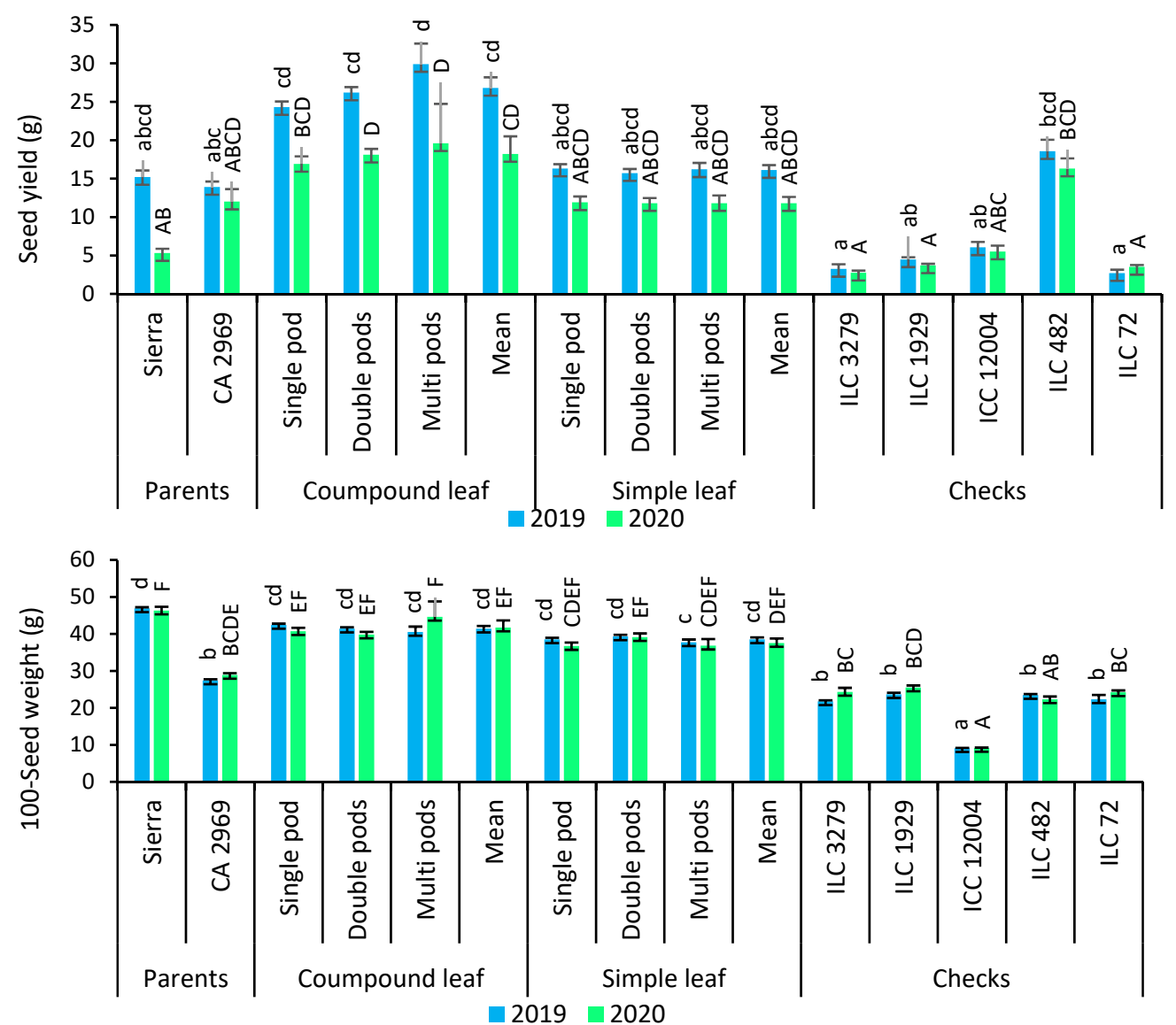

Figure 5. Comparison of compound-leafed versus simple-leafed and multi-podded versus doublepodded and single-podded chickpeas with parents and checks for seed yield and 100-seed weight. Different lowercase letters and uppercase letters represent the significant difference $(p \leq 0.05)$ between the means for 2019 and 2020, respectively.

\subsection{0-Seed Weight}

As shown in Figure 5, 100-seed weight was counted as $41.4 \mathrm{~g}$ for compound-leafed chickpeas, while it was recorded as $38.5 \mathrm{~g}$ for simple-leafed chickpeas in 2019. In 2020, 100 -seed weight was detected as $41.7 \mathrm{~g}$ for compound-leafed chickpeas, whereas it was found as $37.5 \mathrm{~g}$ in 2019. Compound-leafed and single-podded chickpeas ( $42.4 \mathrm{~g}$ ) had superior 100-seed weight, followed by compound-leafed and double-podded, and compoundleafed and multi-podded in 2019. However, the highest 100-seed weight was obtained in compound-leafed and multi-podded chickpeas (44.6 g) in 2020 (Figure 5).

\subsection{Direct and Indirect Relationships of Multi-Podded and Double-Podded Traits on Seed Yield}

Path analyses were carried out to show the direct and indirect relationships of agromorphological traits on seed yield (Tables 3 and 4). In multi-podded chickpeas, the highest direct relationships were lined up for seeds per plant $\left(p=0.733^{*}\right)$ and pods per plant $(p=0.330 *)$, followed by seed weight $\left(p=0.201^{*}\right)$ and leaf shape $\left(p=-0.036^{*}\right)$. The highest indirect relationships on seed yield over seeds per plant were attained as seed weight $\left(p=-2.064^{*}\right)$ and leaf shape $\left(p=-1.453^{*}\right)$ in multi-podded chickpeas (Table 3$)$. 
Table 3. Direct and indirect relationships among agro-morphological traits on seed yield over pods per axil.

\begin{tabular}{|c|c|c|c|c|c|c|c|c|}
\hline \multirow{2}{*}{ Traits } & \multicolumn{8}{|c|}{ Indirect Relationship } \\
\hline & Pods per Axil & LS & FF & DF & PH & PP & SP & SW \\
\hline \multirow{3}{*}{ Leaf shape (LS) } & Single & -0.038 * & $-0.636^{*}$ & $0.493 *$ & $0.162 *$ & $0.659 *$ & $-0.968 *$ & -0.340 * \\
\hline & Double & $-0.42 *$ & -0.41 & 0.069 & 0.338 * & $0.593 *$ & $-0.900 *$ & $-0.304^{*}$ \\
\hline & Multi & $-0.36 *$ & -0.268 & 0.270 & 0.186 & 0.788 & $-1.453 *$ & $-0.721^{*}$ \\
\hline \multirow{3}{*}{$\begin{array}{l}\text { Days to first } \\
\text { flowering (FF) }\end{array}$} & Single & -0.77 * & 0.007 & 0.960 * & 0.008 & -0.22 & 0.015 & 0.005 \\
\hline & Double & -0.07 & -0.49 & 0.939 * & 0.006 & 0.021 & 0.038 & -0.15 \\
\hline & Multi & -0.19 & 0.143 & 0.944 * & 0.013 & $0.372 *$ & -0.444 * & -0.90 * \\
\hline \multirow{3}{*}{$\begin{array}{l}\text { Days to } 50 \% \\
\text { flowering (DF) }\end{array}$} & Single & 0.057 * & $0.922 *$ & 0.025 & -0.26 & 0.064 & -0.74 & -0.37 \\
\hline & Double & 0.011 & $0.925 *$ & 0.067 * & -0.43 & 0.053 & -0.131 & -0.14 \\
\hline & Multi & 0.020 & 0.981 * & -0.73 & -0.40 & $-0.296^{*}$ & $0.353 *$ & 0.085 \\
\hline \multirow{3}{*}{ Plant height (PH) } & Single & $0.113 *$ & 0.048 & -0.159 & -0.09 & -0.97 & 0.339 & $0.216^{*}$ \\
\hline & Double & $0.251 *$ & 0.026 & -0.194 & -0.09 & -0.290 & $0.439 *$ & $0.225 *$ \\
\hline & Multi & 0.152 & 0.148 & -0.437 & -0.12 & -0.349 & 0.386 & 0.272 \\
\hline \multirow{3}{*}{ Pods per plant (PP) } & Single & $0.033 *$ & -0.09 & 0.028 & -0.07 & $0.533 *$ & $0.975 *$ & 0.098 * \\
\hline & Double & $0.036^{*}$ & 0.008 & 0.020 & -0.24 & $0.201 *$ & 0.991 * & 0.090 * \\
\hline & Multi & 0.055 & $0.362 *$ & $-0.277^{*}$ & -0.30 & $0.330 *$ & $1.074^{*}$ & 0.154 * \\
\hline \multirow{3}{*}{ Seeds per plant (SP) } & Single & $-0.48 *$ & 0.006 & -0.32 & 0.024 & $0.963 *$ & 0.420 * & -0.101 * \\
\hline & Double & $-0.52 *$ & 0.013 & -0.47 & $0.035 *$ & $0.945 *$ & 0.796 * & $-0.99 *$ \\
\hline & Multi & $-0.81 *$ & $-0.342 *$ & $0.262 *$ & 0.026 & $0.849 *$ & $0.733 *$ & -0.178 * \\
\hline \multirow{3}{*}{ Seed weight (SW) } & Single & -0.325 * & 0.037 & -0.309 & $0.295^{*}$ & 1.845 * & -1.943 * & 0.194 * \\
\hline & Double & -0.310 * & -0.93 & -0.90 & $0.308^{*}$ & 1.490 * & -1.729 * & 0.266 * \\
\hline & Multi & -0.464 * & $-0.809 *$ & 0.728 & 0.214 & 1.411 * & -2.064 * & 0.201 * \\
\hline
\end{tabular}

Bold data show direct relationships. ${ }^{*}$ Significant at $p<0.05$.

Table 4. Direct and indirect relationships among agro-morphological traits on seed yield over leaf shapes.

\begin{tabular}{|c|c|c|c|c|c|c|c|c|}
\hline \multirow{2}{*}{ Traits } & \multicolumn{8}{|c|}{ Indirect Relationship } \\
\hline & Leaf Shape & PA & FF & DF & PH & PP & SP & SW \\
\hline \multirow{2}{*}{ Pods per axil (PA) } & Compound & $-0.41 *$ & -0.228 & 0.244 & 0.071 & 0.199 & -0.74 & -0.56 \\
\hline & Simple & $-0.45 *$ & $0.376^{*}$ & -0.245 & $0.213^{*}$ & $-0.531 *$ & 0.443 & 0.008 \\
\hline \multirow{2}{*}{ Days to first flowering (FF) } & Compound & -0.20 & $-0.58 *$ & $0.956^{*}$ & -0.18 & 0.074 & -0.12 & -0.03 \\
\hline & Simple & $0.042 *$ & -0.11 & 0.930 * & 0.043 & 0.018 & -0.41 & -0.40 \\
\hline \multirow{2}{*}{ Days to $50 \%$ flowering (DF) } & Compound & 0.021 & $0.932 *$ & $0.065 *$ & -0.16 & -0.19 & -0.56 & -0.13 \\
\hline & Simple & -0.27 & $0.919 *$ & 0.066 & $-0.62 *$ & 0.068 & -0.83 & -0.15 \\
\hline \multirow{2}{*}{ Plant height (PH) } & Compound & 0.039 & -0.113 & -0.101 & -0.16 & -0.100 & 0.288 & $0.225 *$ \\
\hline & Simple & $0.109 *$ & 0.194 & $-0.287^{*}$ & 0.030 & -0.130 & 0.275 & 0.252 * \\
\hline \multirow{2}{*}{ Pods per plant (PP) } & Compound & 0.008 & 0.034 & -0.09 & -0.07 & 0.346 * & 0.985 * & 0.093 * \\
\hline & Simple & $-0.36^{*}$ & 0.011 & 0.042 & -0.17 & $0.271 *$ & $0.977^{*}$ & $0.119 *$ \\
\hline \multirow{2}{*}{ Seeds per plant (SP) } & Compound & -0.03 & -0.05 & -0.25 & 0.020 & $0.952 *$ & $0.655 *$ & $-0.100 *$ \\
\hline & Simple & 0.029 & -0.24 & -0.48 & 0.035 & 0.923 * & $0.745 *$ & $-0.148^{*}$ \\
\hline \multirow{2}{*}{ Seed weight (SW) } & Compound & -0.40 & -0.28 & -0.106 & $0.290 *$ & $1.657 *$ & $-1.856^{*}$ & 0.246 * \\
\hline & Simple & 0.005 & -0.226 & -0.85 & $0.308^{*}$ & $1.085 *$ & $-1.437 *$ & $0.260 *$ \\
\hline
\end{tabular}

Bold data show direct relationships. * Significant at $p<0.05$.

\subsection{Direct and Indirect Relationships of Compound-Leafed Trait on Seed Yield}

The highest direct relationships on seed yield in compound-leafed chickpeas were determined as seeds per plant with $p=0.655^{*}$ and pods per plant with $p=0.346^{*}$, followed by seed weight $\left(p=0.246^{*}\right)$ (Table 4$)$. Seed weight had the highest indirect effect on seed yield over seeds per plant $\left(p=-1.856^{*}\right)$ and pods per plant $\left(p=1.657^{*}\right)$. Seeds per plant $\left(p=0.745^{*}\right)$ and pods per plant $\left(p=0.271^{*}\right)$ had the highest direct effect on seed yield in simple-leafed chickpeas, while the highest indirect effect on seed yield was seed weight over seeds per plant $\left(p=-1.437^{*}\right)$ and pods per plant $\left(p=1.085^{*}\right)$ (Table 4$)$. 
3.11. Principal Component Analysis (PCA) and Hierarchical Cluster Analysis (HCA) Based on Seed Yield

According to the principal component analysis (PCA), three principal components with Eigenvalues $>1$ were found in chickpeas in both years, but the first two components explaining $71.7 \%$ (46.5\% for the PC1 and $25.2 \%$ for the PC2 in 2019$)$ and $72.3 \%$ (46.2\% for the PC1 and $26.1 \%$ for the PC2 in 2020) of the total phenotypic variance are presented in Figure 6. The first axis was positively correlated with seeds per plant (SP), pods per plant (PP), and seed yield (SY), while negatively correlated with days to first flowering (FF) and days to $50 \%$ flowering (DF) in both years (Figure 6A,B). The second axis was positively correlated with FF and DF, but it was negatively correlated with 100-seed weight (SW) and plant height $(\mathrm{PH})$ in both years. It was determined that the compound-leafed chickpeas $(3,4$, and 5) were better than the other chickpeas in terms of SP, PP, and SY in both years (Figure 6A,B). However, compound-leafed and multi-podded chickpeas (5) were the best in terms of these traits in both years.

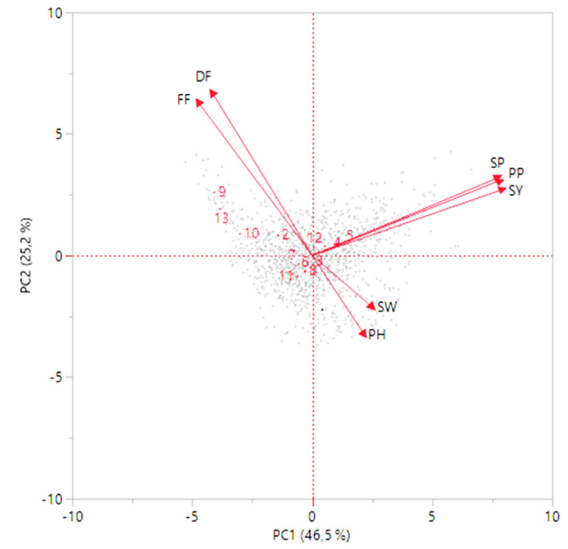

(A)

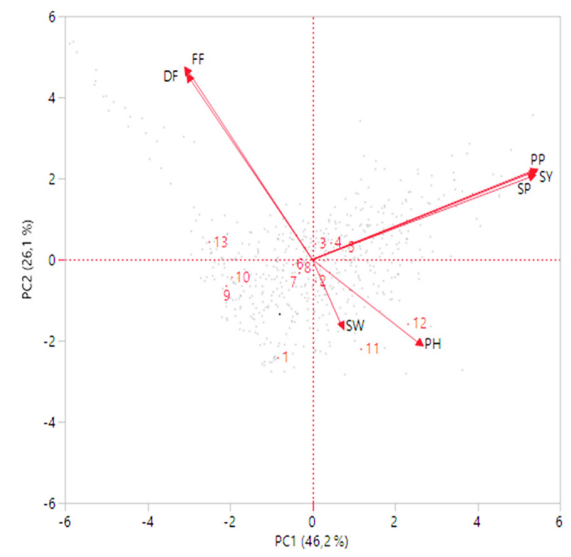

(B)

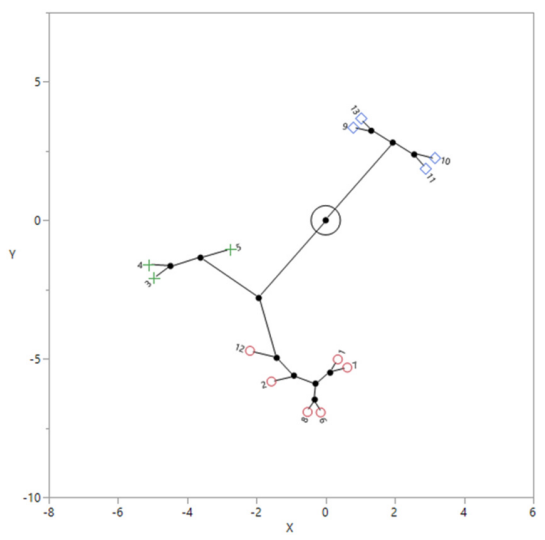

(C)

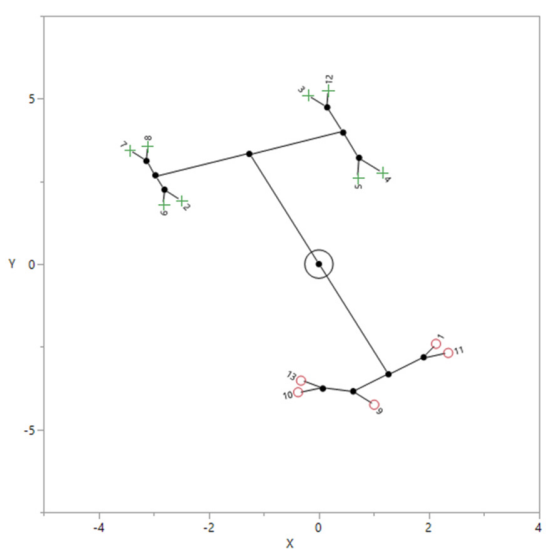

(D)

Figure 6. The principal component analysis (PCA) for agro-morphological traits with compoundleafed, simple-leafed chickpeas, parents, and checks in 2019 (A) and 2020 (B). Constellation plot of compound-leafed, simple-leafed chickpeas, parents, and checks constructed using Ward's method based on hierarchical cluster analysis (HCA) in 2019 (C) and 2020 (D). Different colors (blue, green, and red) indicate distinct groups. The numbers in the figures represent: (1) Sierra, (2) CA 2969, (3) Compound-leafed and single-podded, (4) Compound-leafed and double-podded, (5) Compoundleafed and multi-podded, (6) Simple-leafed and single-podded, (7) Simple-leafed and double-podded, (8) Simple-leafed and multi-podded, (9) ILC 3279, (10) ILC 1929, (11) ICC 12004, (12) ILC 482, (13) ILC 72. 
According to the hierarchical cluster analysis (HCA), compound- and simple-leafed chickpeas, parents, and checks were placed in three groups in 2019 and two groups in 2020 for seed yield (Figure 6C,D). Compound-leafed chickpeas were grouped distinctly from other groups, while simple-leafed chickpeas were gathered in a different group together with Sierra, CA 2969, and ILC 482 in 2019 (Figure 6C). In addition, ILC 3279, ILC 72, ILC 1929, and ICC 12004 had a lower seed yield than these two groups, forming a separate group in 2019 (Figure 6C). Compound-leafed chickpeas, simple-leafed chickpeas, Sierra, and ILC 482 were gathered in a group, while the remaining chickpeas formed in the other group in 2020. However, compound-leafed and simple-leafed chickpeas were grouped in different groups (Figure 6D).

\section{Discussion}

High temperature stress may be one of the most important factors affecting yield in cool season food legumes in the future [49] due to climate change. Among cool season food legumes, chickpeas are also significantly affected by heat stress in the reproductive stage [21,50-52]. A maximum daily temperature above $25^{\circ} \mathrm{C}$ is considered the upper threshold for heat stress in cool season crops [53], and the temperature range for optimum growth and development in chickpeas is $18-29{ }^{\circ} \mathrm{C}$ [1], whereas the chickpeas used in the current study were subjected to extremely high temperature in flowering and pod setting stages of as high as $43.1^{\circ} \mathrm{C}$ (Figure 2 and Figure S1). In general, the seed yield was found to be significantly correlated with $T_{\max \mathrm{FH}}, \mathrm{GDD}_{\mathrm{F}}$, and $\mathrm{GDD}_{\mathrm{FH}}$ (Table 2). Growing degree-days from flowering to harvest $\left(\mathrm{GDD}_{\mathrm{FH}}\right)$ had lower values in compound-leafed chickpeas than that of simple-leafed chickpeas in both years (Table S1). Phenology plays a critical role in resilience to drought and heat stresses, with early flowering providing an advantage by avoiding terminal heat and drought stress by making the reproductive periods early $[6,42,43]$. In the current study, sowing, which was carried out one month earlier in 2020 compared to 2019, extended the vegetative period (about 16 days), but led to the reproductive period being earlier (about 12 days) than the previous year based on the month. However, the sudden extreme temperature conditions (leading to defoliation, leaf drying especially in simple-leafed chickpeas, and flower abortion) occurring at the beginning of the flowering and pod setting periods (Figure 2 and S1) caused a relatively low yield and yield components compared to the previous year (Figures 3-5).

Modifying plant architecture is one of the methods used in plant breeding to increase crop yield, as well as to cope with a/biotic stresses. Morphological and anatomical characteristics of plant leaves are generally related to metabolic type, amount of sun exposure, or water stress [54], and during evolution, nature allows for the formation of the most suitable form in the natural habitat, together with the formation of different leaf forms within the species. Similarly, there are three leaf forms for cultivated chickpeas, including compound, simple, and multipinnate (Figure 1), and the most commonly used varieties in agricultural production have a compound leaf form. With the introduction of simple-leafed chickpea varieties at the end of the 1990s [29,30], many studies were conducted on the agricultural importance of leaf shape in chickpeas $[19,20,34,41]$. Compound-leafed chickpeas were more advantageous in terms of seed yield than that of simple-leafed chickpeas under high temperature stress. In the current study, compound-leafed chickpeas had a $60.7 \%$ higher seed yield than that of simple-leafed chickpeas under heat stress conditions (Figure 5). One of the reasons for the difference in yield may be that the area of a single compound leaf is approximately 2-3 times larger than a single simple leaf, and the compound leaf types have more photosynthetic leaf area, as reported by Abbo et al. [19]. Another reason can because plants can respond to the amount of sunlight and stress in a particular habitat by improving their leaf structural characteristics in accordance with their leaf orientation abilities [54,55], and when compound-leafed chickpeas are exposed to high sunlight, the leaf surface area is reduced by the closing movement of opposite leaflets towards each other (Figure 1). However, simple-leafed chickpeas do not have the ability to narrow the angle of sunlight intake (Figure 1). 
The current study demonstrated that multi-podded chickpeas had more advantages than that of single- and double-podded chickpeas in terms of seed yield and its components under high temperature stress (Figures 3-5). The multi-podded chickpeas had the advantage of $7.8 \%$ and $20.5 \%$ higher seed yield than the double-podded and single-podded chickpeas, respectively. In previous studies, the effects of pods per axil in chickpea on yield were investigated [34-36,38,56-58]. Sheldrake et al. [57] studied the effects of converting double-podded plants to single-podded ones by cutting off one of the flowers at every double-podded node, and concluded that the double-podded character may increase seed yield by $6-11 \%$. Kumar et al. [35] reported that the double podding trait had a yield advantage of $18 \%$ in the $\mathrm{F}_{2}$ and $7 \%$ in recombinant inbred lines. On the other hand, the double podding trait does not provide an advantage on seed yield [38,59]. Furthermore, the double podding trait increases seed yield and therefore can play an important role in stabilizing the chickpea yield [58], and the double-pod gene has a positive effect on the yield stability of chickpeas [38]. It has been suggested that the double podding trait in chickpeas increases the demand for assimilation in the sink during the pod filling period, which in turn accelerates maturity, especially in regions with a short growing season [56]. It is known that heat stress affects the reproductive stage more negatively than the vegetative stage in chickpeas [49]. Heat stress during reproduction reduces the number of flowers, increases flower abortion, causes pollen sterility, and reduces fertilization and the remobilization of assimilates to seeds, as well as a decline in seed number, seed weight, and seed yield [21,60-62].

In addition to double-podded chickpeas, multi-podded chickpeas containing more than two pods in an axil were induced by spontaneous mutations [34,63,64]. However, no study has been conducted on the response to high temperature stress in multi-podded chickpeas. In the current study, the effects of both pods per axil and leaf shape on the yield and yield components were investigated under heat stress conditions. Compound-leafed chickpeas had a considerable yield advantage over the simple-leafed chickpeas, the number of pods per axil also affected seed yield (Figure 5). The number of pods per axil had not had a significant effect on seed yield in simple-leafed chickpeas, while the increase in the number of pods per axil in compound-leafed chickpeas showed a positive and significant effect (Figure 5).

The path analysis provides the separating of the direct and indirect relationships among traits on the seed yield in chickpea [14], and the main purpose of the path analysis in the current study was to determine the direct or indirect relationship between seed yield and yield components based on leaf shape and pods per axil. The number of seeds and pods per plant, 100-seed weight, and pods per axil had the highest direct effect on seed yield in both compound-leafed and simple-leafed chickpeas (Table 4). In addition, for seeds and pods per plant, 100-seed weight had the highest direct effect on seed yield in multi-podded chickpeas, and therefore, these traits should be considered as the selection criteria to select superior chickpeas (Table 3). Moreover, 100-seed weight indirectly affected the seed yield over the number of seeds per plant in multi-podded chickpeas (Table 3).

Principal component analysis (PCA) was performed to examine how chickpeas were classified according to leaf shape and pods per axil, parents, and checks. PCA results showed that the maximum variation was contributed by yield parameters such as seeds per plant (SP), pods per plant (PP), and seed yield (SY) for PC1, and phenological traits such as days to flowering (DF) and days to 50\% flowering (FF) for PC2 (Figure 6A,B).

Hierarchical cluster analysis (HCA) was carried out to show chickpea groups and agro-morphological traits under heat stress conditions, and three groups were formed in 2019 (Figure 6C). Compound-leafed and simple-leafed chickpeas were formed in two separate groups in terms of yield in 2020 (Figure 6D). Chickpeas with multi-pods with the highest yield were differentiated from the single-pod and double-pods (Figure 6C,D).

In conclusion, plants with multi-pods and compound leaf traits had the highest seed yield, followed by plants with double-pods and compound leaves. On the other hand, plants with single-pod and simple leaves had the lowest yield, but they had large seeds than 
their counterparts. The number of seeds and pods per plant and 100-seed weight had the highest determinant of seed yield under heat stress conditions. Multi-pods per peduncle and compound leaf traits had an obviously enormous advantage in "kabuli" chickpeas under heat stress conditions. The plant shapes that nature has evolved for millions of years, which are mostly found in wild plants, have been proven by the current study to have a better fitness ability than plants shaped by human hands.

Supplementary Materials: The following supporting information can be downloaded at https: / /www.mdpi.com/article/10.3390/agronomy12030557/s1. Table S1: Growing degree-days of chickpeas having leaf shape and number of pods per axil in comparison to parents and checks in 2019 and $2020\left({ }^{\circ} \mathrm{C}\right)$. Figure S1: Daily maximum $\left(T_{\max }\right)$, minimum $\left(T_{\min }\right)$ and average $\left(T_{\text {ave }}\right)$ temperatures during flowering (May) and pod setting (June) stages in 2019 and 2020 growing seasons. Threshold temperature is considered as $29^{\circ} \mathrm{C}$.

Author Contributions: Conceptualization, C.T. and T.E.; methodology, T.E.; software, T.E.; validation, H.S.; formal analysis, H.S.; investigation, T.E.; resources, C.T.; data curation, D.S.; writing—original draft preparation, C.T. and T.E.; writing-review and editing, D.S., H.C., B.A., M.A. and H.O.; visualization, T.E. and H.S.; supervision, C.T. All authors have read and agreed to the published version of the manuscript.

Funding: This research received no external funding.

Institutional Review Board Statement: Not applicable.

Informed Consent Statement: Not applicable.

Data Availability Statement: Not applicable.

Acknowledgments: The current study is the second part of MSc thesis of the first author (T.E.). We are thankful to Fred J. Muehlbauer (Washington State University, Pullman, WA) and J. Gil (Universidad de Cordoba, Cordoba, Spain) for providing seeds of chickpeas.

Conflicts of Interest: The authors declare no conflict of interest.

\section{References}

1. Van der Maesen, L.J.G. A Monograph of the Genus, with Special Reference to the Chickpea (Cicer arietinum L.), Its Ecology and Cultivation; Veenman: Wageningen, The Netherlands, 1972.

2. Kumar, J.; Abbo, S. Genetics of flowering time in chickpea and its bearing on productivity in semiarid environments. Adv. Agron. 2001, 72, 107-138.

3. Zohary, D.; Hopf, M. Domestication of Plants in the Old World: The Origin and Spread of Cultivated Plants in West Asia, Europe, and the Nile Valley; Oxford University Press: Oxford, UK, 2000.

4. Toker, C.; Yadav, S.S. Legumes cultivars for stress environments. In Climate Change and Management of Cool Season Grain Legume Crops; Springer: Berlin/Heidelberg, Germany, 2010; pp. 351-376.

5. Food and Agriculture Organisation Statistics Database. Available online: http://www.fao.org/faostat/en/\#data/QC (accessed on 16 April 2021).

6. Toker, C.; Mutlu, N. Breeding for abiotic stresses. In Biology and Breeding of Food Legumes; CABI: Wallingford, UK, 2011; pp. 241-261.

7. Basu, P.; Ali, M.; Chaturvedi, S. Terminal Heat Stress Adversely Affects Chickpea Productivity in Northern India-Strategies to Improve Thermotolerance in the Crop under Climate Change. W3 Workshop Proceedings: Impact of Climate Change on Agriculture. 2009. Available online: https:/ / www.isprs.org/proceedings/xxxviii/ 8-W3/B3/B3-1-29.pdf (accessed on 15 July 2021).

8. Devasirvatham, V.; Gaur, P.M.; Raju, T.N.; Trethowan, R.M.; Tan, D.K.Y. Field response of chickpea (Cicer arietinum L.) to high temperature. Field Crops Res. 2015, 172, 59-71. [CrossRef]

9. Laranjeira, S.; Fernandes-Silva, A.; Reis, S.; Torcato, C.; Raimundo, F.; Ferreira, L.; Carnide, V.; Marques, G. Inoculation of plant growth promoting bacteria and arbuscular mycorrhizal fungi improve chickpea performance under water deficit conditions. Appl. Soil Ecol. 2021, 164, 103927. [CrossRef]

10. Hatfield, J.L.; Prueger, J.H. Temperature extremes: Effect on plant growth and development. Weather Clim. Extrem. 2015, 10, 4-10. [CrossRef]

11. The Intergovernmental Panel on Climate Change (IPCC). Climate Change 2007: Synthesis Report. Summary for Policymakers. 2007. Available online: https:/ / www.ipcc.ch/site/assets/uploads/2018/02/ar4_syr_spm.pdf (accessed on 17 October 2021). 
12. Jumrani, K.; Bhatia, V.S. Impact of elevated temperatures on growth and yield of chickpea (Cicer arietinum L.). Field Crops Res. 2014, 164, 90-97. [CrossRef]

13. Upadhyaya, H.D.; Dronavalli, N.; Gowda, C.; Singh, S. Identification and evaluation of chickpea germplasm for tolerance to heat stress. Crop Sci. 2011, 51, 2079-2094. [CrossRef]

14. Canci, H.; Toker, C. Evaluation of yield criteria for drought and heat resistance in chickpea (Cicer arietinum L.). J. Agron. Crop Sci. 2009, 195, 47-54. [CrossRef]

15. Farooq, M.; Nadeem, F.; Gogoi, N.; Ullah, A.; Alghamdi, S.S.; Nayyar, H.; Siddique, K.H.M. Heat stress in grain legumes during reproductive and grain-filling phases. Crop. Pasture. Sci. 2017, 68, 985-1005. [CrossRef]

16. Krishnamurthy, L.; Gaur, P.; Basu, P.; Chaturvedi, S.; Tripathi, S.; Vadez, V.; Rathore, A.; Varshney, R.K.; Gowda, C.L.L. Large genetic variation for heat tolerance in the reference collection of chickpea (Cicer arietinum L.) germplasm. Plant Genet. Resour. 2011, 9, 59-69. [CrossRef]

17. Paul, P.J.; Samineni, S.; Thudi, M.; Sajja, S.B.; Rathore, A.; Das, R.R.; Khan, A.W.; Chaturvedi, S.K.; Lavanya, G.R.; Varshney, R.K.; et al. Molecular mapping of QTLs for heat tolerance in chickpea. Int. J. Mol. Sci. 2018, 19, 2166. [CrossRef] [PubMed]

18. Canci, H.; Toker, C. Evaluation of annual wild Cicer species for drought and heat resistance under field conditions. Genet. Resour. Crop Evol. 2009, 56, 1-6. [CrossRef]

19. Abbo, S.; Goren, O.; Saranga, Y.; Langensiepen, M.; Bonfil, J.D. Leaf shape $\times$ sowing density interaction affects chickpea grain yield. Plant Breed. 2013, 132, 200-204. [CrossRef]

20. Bonfil, D.J.; Goren, O.; Mufradi, I.; Lichtenzveig, J.; Abbo, S. Development of early-flowering Kabuli chickpea with compound and simple leaves. Plant Breed. 2007, 126, 125-129. [CrossRef]

21. Devasirvatham, V.; Gaur, P.M.; Mallikarjuna, N.; Tokachichu, R.N.; Trethowan, R.M.; Tan, D.K.Y. Effect of high temperature on the reproductive development of chickpea genotypes under controlled environments. Funct. Plant Biol. 2012, 39, 1009-1018. [CrossRef]

22. Farooq, M.; Ullah, A.; Lee, D.-J.; Alghamdi, S.S.; Siddique, K.H. Desi chickpea genotypes tolerate drought stress better than kabuli types by modulating germination metabolism, trehalose accumulation, and carbon assimilation. Plant Physiol. Biochem. 2018, 126, 47-54. [CrossRef] [PubMed]

23. Cubero, J.I. Morphology of chickpea. In The Chickpea; Saxena, M.C., Singh, K.B., Eds.; CAB International: Wallingford, UK, 1987; pp. 35-66.

24. Muehlbauer, F.J.; Singh, K.B. Genetics of chickpea. In The Chickpea; Saxena, M.C., Singh, K.B., Eds.; CAB International: Wallingford, UK, 1987; pp. 99-125.

25. Pundir, R.P.S.; Mengesha, M.H.; Reddy, K.N. Leaf types and their genetics in chickpea (Cicer arietinum L.). Euphytica 1990, 45, 197-200. [CrossRef]

26. Rao, N.K.; Pundir, R.P.S.; Vandermaesen, L.J.G. Inheritance of some qualitative characters in chickpea (Cicer arietinum L.). Proc. Indian Acad. Sci. 1980, 89, 497-503. [CrossRef]

27. Toker, C.; Ceylan, F.O.; Inci, N.E.; Yildirim, T.; Cagirgan, M.I. Inheritance of leaf shape in the cultivated chickpea (Cicer arietinum L.). Turk. J. Field Crops 2012, 17, 16-18.

28. Toker, C.; Berger, J.; Eker, T.; Sari, D.; Sari, H.; Gokturk, R.S.; Kahraman, A.; Aydin, B.; von Wettberg, E.J. Cicer turcicum: A new Cicer species and its potential to improve chickpea. Front. Plant Sci. 2021, 12, 662891. [CrossRef]

29. Muehlbauer, F.J.; Kaiser, W.J.; Kusmenoglu, I. Registration of “Dwelley" Chickpea. Crop Sci. 1998, 38, 283. [CrossRef]

30. Muehlbauer, F.J.; Kaiser, W.J.; Kusmenoglu, I. Registration of "Sanford" Chickpea. Crop Sci. 1998, 38, 282. [CrossRef]

31. Singh, K.B.; Weigand, S. Registration of three leafminer-resistant chickpea germplasm lines: ILC 3800, ILC 5901, and ILC 7738. Crop Sci. 1996, 36, 472. [CrossRef]

32. Toker, C.; Adak, A.; Sari, D.; Sari, H.; Ceylan, F.O.; Canci, H.; Ikten, C.; Erler, F.; Upadhyaya, H.D. Registration of AWC 612M chickpea mutant germplasm line resistant to leaf miner (Liriomyza cicerina). J. Plant Regis. 2019, 13, 87-90. [CrossRef]

33. Toker, C.; Lluch, C.; Tejera, N.A.; Serraj, R.; Siddique, K.H.M. Abiotic stresses. In Chickpea Breeding and Management; Yadav, S.S., Chen, W., Eds.; CABI: Wallingford, UK, 2007; pp. 474-496.

34. Kivrak, K.G.; Eker, T.; Sari, H.; Sari, D.; Akan, K.; Aydinoglu, B.; Catal, M.; Toker, C. Integration of extra-large-seeded and double-podded traits in chickpea (Cicer arietinum L.). Agronomy 2020, 10, 901. [CrossRef]

35. Kumar, J.; Srivastava, R.K.; Ganesh, M. Penetrance and expressivity of the gene for double podding in chickpea. J. Hered. 2000, 91, 234-236. [CrossRef]

36. Yasar, M.; Ceylan, F.O.; Ikten, C.; Toker, C. Comparison of expressivity and penetrance of the double podding trait and yield components based on reciprocal crosses of kabuli and desi chickpeas (Cicer arietinum L.). Euphytica 2014, 196, 331-339. [CrossRef]

37. Rubio, J.; Flores, F.; Moreno, M.T.; Cubero, J.I.; Gil, J. Effects of the erect/bushy habit, single/double pod and late/early flowering genes on yield and seed size and their stability in chickpea. Field Crops Res. 2004, 90, 255-262. [CrossRef]

38. Rubio, J.; Moreno, M.T.; Cubero, J.I.; Gil, J. Effect of the gene for double pod in chickpea on yield, yield components and stability of yield. Plant Breed. 1998, 117, 585-587. [CrossRef]

39. Muehlbauer, F.J.; Temple, S.R.; Chen, W. Registration of 'Sierra' chickpea. Crop Sci. 2004, 44, 1864-1865. [CrossRef]

40. Rubio, J.; Moreno, M.T.; Martinez, C.; Gil, J. Registration of CA2969, an ascochyta blight resistant and double-podded chickpea germplasm. Crop Sci. 2003, 43, 1567-1568. [CrossRef] 
41. Eker, T.; Sari, D.; Sari, H.; Tosun, H.S.; Toker, C. A kabuli chickpea ideotype. Sci. Rep. 2022, 12, 1-17. [CrossRef] [PubMed]

42. Berger, J.D.; Ali, M.; Basu, P.S.; Chaudhary, B.D.; Chaturvedi, S.K.; Deshmukh, P.S.; Dharmaraj, P.S.; Dwivedi, S.K.; Gangadhar, G.C.; Gaur, P.M.; et al. Genotype by environment studies demonstrate the critical role of phenology in adaptation of chickpea (Cicer arietinum L.) to high and low yielding environments of India. Field Crops Res. 2006, 98, 230-244. [CrossRef]

43. Berger, J.D.; Turner, N.C.; Siddique, K.H.M.; Knights, E.J.; Brinsmead, R.B.; Mock, I.; Edmondson, C.; Khan, T.N. Genotype by environment studies across Australia reveal the importance of phenology for chickpea (Cicer arietinum L.) improvement. Aust. J. Agric. Res. 2004, 55, 1071-1084. [CrossRef]

44. Lamichaney, A.; Parihar, A.K.; Hazra, K.K.; Dixit, G.P.; Katiyar, P.K.; Singh, D.; Singh, A.D.; Kumar, N.; Singh, N.P. Untangling the influence of heat stress on crop phenology, seed set, seed weight, and germination in field pea (Pisum sativum L.). Front. Plant Sci. 2021, 12, 437. [CrossRef] [PubMed]

45. Ellis, R.; Covell, S.; Roberts, E.; Summerfield, R. The influence of temperature on seed germination rate in grain legumes: II. Intraspecific variation in chickpea (Cicer arietinum L.) at constant temperatures. J. Exp. Bot. 1986, 37, 1503-1515. [CrossRef]

46. Krese, G.; Prek, M.; Butala, V. Analysis of building electric energy consumption data using an improved cooling degree day method. Stroj. Vestn. J. Mech. Eng. 2012, 58, 107-114. [CrossRef]

47. Dewey, D.R.; Lu, K. A Correlation and path-coefficient analysis of components of crested wheatgrass seed production. Agron. J. 1959, 51, 515-518. [CrossRef]

48. Chrigui, N.; Sari, D.; Sari, H.; Eker, T.; Cengiz, M.F.; Ikten, C.; Toker, C. Introgression of resistance to leafminer (Liriomyza cicerina Rondani) from Cicer reticulatum Ladiz. to C. arietinum L. and relationships between potential biochemical selection criteria. Agronomy 2021, 11, 57. [CrossRef]

49. Sita, K.; Sehgal, A.; HanumanthaRao, B.; Nair, R.M.; Vara Prasad, P.; Kumar, S.; Gaur, P.M.; Farooq, M.; Siddique, K.H.M.; Varshney, R.K.; et al. Food legumes and rising temperatures: Effects, adaptive functional mechanisms specific to reproductive growth stage and strategies to improve heat tolerance. Front. Plant Sci. 2017, 8, 1658. [CrossRef]

50. Malhotra, R.S.; Saxena, M.C. Screening for cold and heat tolerance in coolseason food legumes. In Breeding for StressTolerance in Cool Season Food Legumes; Singh, K.B., Saxena, M.C., Eds.; John Wiley \& Sons Singh: Chichester, UK, 1993; pp. $227-244$.

51. Singh, K.B.; Malhotra, R.S.; Halila, M.H.; Knights, E.J.; Verma, M.M. Current status and future strategy in breeding chickpea for resistance to biotic and abiotic stresses. Euphytica 1993, 73, 137-149. [CrossRef]

52. Wery, J.; Silim, S.N.; Knights, E.J.; Malhotra, R.S.; Cousin, R. Screening techniques and sources of tolerance to extremes of moisture and air temperature in cool season food legumes. In Expanding the Production and Use of Cool Season Food Legumes; Muehlbauer, F.J., Kaiser, W.J., Eds.; Springer: Dordrecht, The Netherlands, 1994; pp. 439-456.

53. Wahid, A.; Gelani, S.; Ashraf, M.; Foolad, M.R. Heat tolerance in plants: An overview. Environ. Exp. Bot. 2007, 61, 199-223. [CrossRef]

54. Smith, W.K.; Vogelmann, T.C.; DeLucia, E.H.; Bell, D.T.; Shepherd, K.A. Leaf form and photosynthesis: Do leaf structure and orientation interact to regulate internal light and carbon dioxide? BioScience 1997, 47, 785-793. [CrossRef]

55. Katul, G.; Manzoni, S.; Palmroth, S.; Oren, R. A stomatal optimization theory to describe the effects of atmospheric $\mathrm{CO}_{2}$ on leaf photosynthesis and transpiration. Ann. Bot. 2010, 105, 431-442. [CrossRef]

56. Anbessa, Y.; Warkentin, T.; Bueckert, R.; Vandenberg, A. Short internode, double podding and early flowering effects on maturity and other agronomic characters in chickpea. Field Crops Res. 2007, 102, 43-50. [CrossRef]

57. Sheldrake, A.; Saxena, N.; Krishnamurthy, L. The expression and influence on yield of the 'double-podded'character in chickpeas (Cicer arietinum L.). Field Crops Res. 1978, 1, 243-253. [CrossRef]

58. Singh, O.; van Rheenen, H. Genetics and contributions of the multiseeded and double-podded characters to grain yield of chickpea. Indian J. Pulses Res. 1994, 7, 97-102.

59. Knights, E. The double-podded gene in chickpea improvement. Int. Chickpea Newsl. 1987, 17, 6-7.

60. Devasirvatham, V.; Gaur, P.M.; Mallikarjuna, N.; Raju, T.N.; Trethowan, R.M.; Tan, D.K. Reproductive biology of chickpea response to heat stress in the field is associated with the performance in controlled environments. Field Crops Res. 2013, 142, 9-19. [CrossRef]

61. Kaushal, N.; Awasthi, R.; Gupta, K.; Gaur, P.; Siddique, K.H.; Nayyar, H. Heat-stress-induced reproductive failures in chickpea (Cicer arietinum) are associated with impaired sucrose metabolism in leaves and anthers. Funct. Plant Biol. 2013, 40, 1334-1349. [CrossRef]

62. Wang, J.; Gan, Y.; Clarke, F.; McDonald, C. Response of chickpea yield to high temperature stress during reproductive development. Crop Sci. 2006, 46, 2171-2178. [CrossRef]

63. Srinivasan, S.; Gaur, P.; Chaturvedi, S.; Rao, B. Allelic relationships of genes controlling number of flowers per axis in chickpea. Euphytica 2006, 152, 331-337. [CrossRef]

64. Gaur, P.; Gour, V. A gene producing one to nine flowers per flowering node in chickpea. Euphytica 2002, 128, 231-235. [CrossRef] 